\title{
A Sistemática Penal do Estatuto
}

\author{
Celso de Magalhães
}

\section{O DIREITO DE PUNIR}

$\mathrm{O}$

Estado pcde punir; daí a razão do Direito Penal, conjunto de normas que regulam essa faculdade, definindo os crimes e lhes estabelecendo as sanções.

Justifica-se o direito de punir, por vários sistemas que podem ser diferentemente classificados:

- morais, subjetivos ou absolutos

- utilitários, objetivos ou relativos

- ecléticcs ou mistos.

O sistema se diz subjetivo, quando tem por fundamento o Princípio de Moral, que manda punir o mal e premiar o bem. A pena, para tais sistemas, é um mal que o delinqüente terá de sofrer, como conseqüência do dano por êle infligido a outrem: malum passionis propter malum actions. A pena, para tais sistemas, tem caráter exclusivamente expiatório: pune-se quia peccatum est.

O sistema se diz objetivo quando tem por fundamento o caráter profilático da pena; para êle, a pena se destina a intimidar os que, possivelmente, poderiam também delinqüir. Não se aplica, portanto, a pena segundo o princípic - quia peccatum est, mas por outro muito diferente - ut ne peccetur.

Os sistemas morais fazem tábula rasa do interêsse social, visando apenas ao indivíduo; ao contrário, os sistemas utilitários ignoram o indivíduo, considerando apenas a sociedade. Os sistemas subjetivos confundem crime com pecado e vício, misturando, assim, Direito, Moral e Religião; os sistemas objetivos, por sua vez, possibilitam excessos penais, pois sempre haveria a justificá-los as elásticas razões de Estado.

PCr isso, surgiram os sistemas ecléticos, num esfôrço para conciliar os dois sistemas que, separadamente, não satisfaziam à consciência jurídica: o direito de punir se justificaria pelo princípio da justiça absoluta, limitado, entretanto, pelo princípio da utilidade social. Não se puniria, conseqüentemente, quia peccatum est, nem, tampouco, ut ne peccetur, mas, sim, pela conjugação de ambos: quia peccatum est et ne peccetur. Pune-se pcrque o ato, em si mesmo, é danoso e ainda por ser prejudicial à conservação do grupo social. 


\section{ESCOLAS CRIMINOLÓGICAS}

Os estudiosos dos assuntos penais reuniram-se em grupos diferentes, dando origem a várias escolas.

A Escola Clássica dava importância exclusiva ao crime em si; preccupava-se com o fato delituoso, considerando-o entidade abstrata, ficção jurídica, cujas características deveriam ser predominantes na fixação da pena, fôsse qual fôsse o agente dêsse fato, o criminoso.

Essa concepçãc deu origem a verdadeiras crueldades: a pena era sempre um ato de vingança social contra o delinqüente, e isso até mesmo após a revolução causada por BECCARIA, no século XVIII, com seu célebre livro - Deidelitti e delle pene.

Ainda CARRARA continuou dando importância apenas ao estudo do crime, sem atenção à pessoa do criminoso.

Tal concepção provocou, como não poderia deixar de provocar, o movimento oposto da Escola Antropológica, cnde pontificaram LoMBroso, FERRI, GAROFAlO: o criminoso era tudo; o crime, em si, nada, o que não deixava de ser outro exagêro.

A Escola Clássica considera o homem imputável, porque é livre em suas ações: seu postulado básico é, portanto, o livre arbítrio: podendo o hcmem discernir entre o bem e o mal, e optando pelo mal, deverá ser punido.

Para a Escola Antropológica, também chamada positiva, ac revés, o homem não é livre nas suas decisões, não podendo, pois, discernir, entre o bem e o mal; assim, se porventura delinqüe, terá de ser punido apenas porque se tornou temível para a sociedade, que dessa forma se defende dêle. A pena tem, pois, caráter de autcriefesa social; não há uma responsabilidade individual, mas social.

Deslocando-se a Escola Positiva para um exagêro oposto ao da Escola Clássica, não satisfez a todos os estudiosos, pelo que surgiu a Terza Scuola, a Esccla Eclética ou crítica. Essa nova escola é, como a antropológica, determinista: o homem é conduzido à prática do crime, não the sendo facultado discernir livremente, mas, a despeito disso, torna-se moralmente responsável, pois se não é livre na concepção, não deixa de o ser na execução: libertas non est volendi sed quae volumus faciendi.

\section{CRIMINOSOS}

A Escola Clássica e a Eścola Antropológica pura perderam terreno. Ora, admitido que o crime resulta de fatôres antropológicos e mesológiccs, necessário se tornava classificar os tipos humanos por suas possibilidades criminais, pela tendência a delinqüir. Isso se impunha tanto mais, quanto deveria variar o grau de imputabilidade de cada um, conforme a classificação que the ccubesse na escala estabelecida.

Se bem que não se atenham, hoje, os criminalistas, aos esquemas de FERRr ou de Lombroso, nenhum dêles deixa de reconhecer que cada criminoso é um caso a ser considerado à parte, a fim de determinar-se o grau de liberdade de que dispunha êle no momento de decidir. 
$\mathrm{E}$ isso está de tal forma incorporado à consciência jurídica dos povos cultos, que a própria Constituição Federal, no seu art. 141, § 29, dispõe, verbis:

"A lei penal regulará a individualização da pena..."

e, secundando-a no que dispõe, diz o Código Penal, no seu art. 42, verbis:

"Compete ao juiz, atendendo aos antecedentes e à personalidade do agente, à intensidade do dolo ou grau da culpa aos motivos, às circunstâncias e conseqüências do crime:

"I - determinar a pena aplicável, dentre as cominadas alternativamente;"

"II - fixar, dentro dos limites legais, a quantidade da pena aplicável.”

\section{FUNÇÃO DA PENA}

A pena não possui, modernamente, o caráter de castigo, nem é imposta por vingança scicial: ela tem caráter profilático, pois visa à readaptação do delinqüente à sociedade. Daí seu caráter individual: a pena, a despeito de ser ditada pelo fato delituoso, gradua-se conforme a personalidade do agente do crime.

Por isso, para tôda pena há um limite mínimo e um limite máximo, dentro dos quais decide o arbítrio do julgador, depois de analisar circunstâncias agravantes e atenuantes de cada culpado. Quem comete, por exemplo, crime de peculato, fica sujeito às penas cumulativas de reclusão e multa; não poderá sofrer outras mais graves ou mais leves, porque sòmente essas foram fixadas para aquêle fato criminoso. Mas tanto a pena de reclusäo, como a de multa podem variar em quantidade, respectivamente, desde 2 até 10 anos, e de 5 até 50 mil cruzeiros, conforme forem a personalidade do delinqüente, as condições e circunstâncias do crime.

O fixar-se uma só pena para cada crime seria regressar à Escola Clássica, vingando-se, no criminoso, a ofensa irrogada à scciedade.

A Criminologia moderna adota princípio semelhante ao da Medicina: assim como não há doença, mas doente, não há crime, mas criminoso.

\section{DISCIPLINA}

As relações entre $\sigma$ servidor e o Estado assentam numa ordenação juridica bem caracterizada.

Tôda relação jurídica há de basear-se no Direito como doutrina, como fato social, como Ciência, e não num amontoado de regras esdrúxulas e desconexas, geradas pelo capricho de legislador indcuto.

Como ciência, o Direito não constitui compartimento estanque, mas terá de relacionar-se a várias ciências, em cujos princípios irá haurir os fundamentos para as normas que estabelece.

Assim, as relações entre o servidor e o Estado devem ser cientificamente estabelecidas, não podendo constituir disposições que apenas expressem o 
poder soberano do Estado em impor ao mais fraco aquilo que, na sua onipotência, pode, mas não deveria fazer.

O exercício da função pública impõe deveres ao servidor, dos quais uns são de caráter disciplinar e outros de caráter penal.

Os deveres disciplinares são aquêles que se referem:

- à ordem dos trabalhos

- à hierarquia.

Os deveres penais são os que assim forem considerados no Código e Leis Penais, pois

$$
\text { "crime é a violação imputâvel da lei penal". }
$$

Pela violação dos deveres a que está sujeitc, podem ser aplicadas ao servidor penas disciplinares e criminais.

Quando se trata de crime, cai o servidor sob a sistemática do Direito Penal, e o fato praticado ficará sob a apreciação do Juiz togado, homem de cultura e formação jurídica, técnico capaz de bem sopesar atenuantes e agravantes, para graduar a pena na justa medida requerida pela individualidade do criminoso.

Quando se trata de falta disciplinar, porém...

Daí certas contradições no apreciar o mesmo fato na esfera administrativa e na esfera judiciária: para a autoridade administrativa, prevalece o arbítrio; para a autoridade judiciária, a ciência do Direito. Enquanto uma procura impor sua vontade, a outra procura aplicar princípios racionalmente estabelecidos.

\section{PENAS ESTATUTÁRIAS}

Dispõe o Estatuto dos Funcionários Públicos Civis da União, no seu art. 201, verbis:

"São penas disciplinares:

$$
\begin{aligned}
& \text { "I - Repreensão } \\
& \text { II - Multa } \\
& \text { III — Suspensão } \\
& \text { IV - Destituição de Função } \\
& \text { V - Demissão } \\
& \text { VI - Cassação de aposentadoria ou dispcnibilidade." }
\end{aligned}
$$

Depois de enumerar as penas, deixa o EF o campo livre para sua imposição, pois, art. 202, verbis:

"Na aplicação das penas disciplinares serão consideradas a natureza e a gravidade da infração, e os dancs que dela provierem para o serviço público."

Esse critério é o mesmo da Escola Clássica: sòmente o ato é que dita a peną; a personalidade do delinqüente não importa. 
Dir-se-á que falta disciplinar não é crime e que, portanto, essa aproximação é inconsistente. Mas não é tal; não existem duas Penclogias, duas sistemáticas penais: o direito de punir é um só e terá de fundamentar-se, seja qual fôr $\mathrm{o}$ aspecto de que se revista, no mesmo princípio. $\mathrm{O}$ que distingue a falta disciplinar do crime é que a primeira é violação de uma norma de serviço ou de dever de obediência, ao passo que $c$ crime é a violação de uma regra essencial à ordem social.

Parece que o legislador estatutário teve uma intenção, mas foi traído ao redigir o que pensou: o que se sabe, e está certo, é que não se aplicará, necessàriamente, a pena de repreensão à primeira falta cometida, mas que, dada a gravidade dela, poder-se-á aplicar mesmo a mais grave, que é a de demissão.

Êsse seria o princípio da Escola Eclética, o mais justo, tanto para a sociedade como para o indivíduo.

Comentando o art. 202/EF, diz Contreira dE CARvalho, verbis:

"Não dá, assim, o Estatuto acolhida ao princípio da gradação de penas relativamente à ordem da perpetração das faltas ccmetidas... E ainda êsse um traço diferencial entre o Direito Penal e o Disciplinar. Naquele, leva-se em conta a condição de primáric do indiciado e outras circunstâncias que, no Direito Administrativo, não são consideradas. $\mathrm{Na}$ apuração da responsabilidade administrativa do acusado, leva a Administração em conta, apenas, as circunstâncias agravantes. Procedimento unilateral que contraria os fins do Direito."

A despeito dessa rigidez estatutária, nada há que objetar quanto às penas de repreensão, suspensão e destituição de função.

Com efeito, repreensãc, que se aplica nas faltas leves, nada mais é que uma censura escrita, não admitindo gradação, pela própria natureza de que se reveste.

O mesmo ocorre com a destituição de função: é destituído quem ocupa uma função gratificada e nela procede com falta de exação, provada em processo administrativo.

A pena de suspensão é, em si mesma, graduável, pois pode variar até o máximo de 90 dias. É verdade que, segundo o art. $202 / \mathrm{EF}$, nessa graduação, a autoridade terá de ater-se à gravidade da falta, mas o que se verifica é que todo julgador de formação jurídica age, ainda que subconscientemente, tendo em vista as condições do servidor, atenuando-lhe ou agravando o ato praticado.

Aplica-se a pena de suspensão nas reincidências em faltas ieves ou nas seguintes faltas graves:

- referir-se de modo depreciativo às autoriadades públicas

- retirar da repartição, sem licença, documento ou objeto, desde que isso não constitua crime

- promover manifestação de aprêço ou desapreço na repartição

- fazer ou subscrever lista de donativos na repartição. 


\section{DISPOSITIVOS INócuOS}

Mandando punir as manifestações de aprêço e as listas de donativos, manteve o Estatuto atual dispositivos universalmente reconhecidos inócuos do Estatuto antericr. Perdeu êle a excelente oportunidade de mandar cancelar uma proibição a que ninguém obedece, a começar pelas mais elevadas autoridades. $\mathrm{E}$ isso não me parece mal nenhum: as manifestações de aprêço e as listas de donativos revelam a excelência de moral de uma equipe de trabalho. Sempre se fizeram e se fazem, nas repartições, listas de donativos e manifestações de aprêço. Se alguém, procurando fugir a um convite para qualquer delas, invoca a proibição estatutária, fica mal visto.

O legislador estatutário sabia disso: todos o sabem. Faltou-lhe, porém, o necessário senso sociológico: a lei positiva não erradica o costume sòlidamente estabelecido; a função da lei é reconhecer o costume e dar-lhe forma jurídica, não contrariá-lo.

Assim, não há autoridade que puna alguém por promover manifestação de aprêço ou lista de donativo. $E$ ainda mais com a pena de suspensão.

\section{DEMISSÃO}

Mas onde a questão avulta de importância é nas faltas punidas com a pena de demissãc ou cassação de aposentadoria e disponibilidade, equivalenres, para todos os fins.

Com efeito, será imposta a pena de demissão nos casos de:

- crime contra a Administração Pública

- incontinência pública escandalosa, vícios de jogos proibidos, embriaguez habitual

- insubordinação grave em serviço

- ofensa física em serviço contra colega ou estranho, salvo legítima defesa

- valer-se do cargo ou função para obter vantagens indevidas

- coagir ou aliciar subordinados para fins políticos

-- participar de gerência cu administração de emprêsa

- praticar a usura

- cometer a pessoa estranha, fora dos casos da lei, atribuição sua.

Não satisfeito em iniciar a lista pelos crimes contra a Administração Pública, resolveu o legislador estatutário citar, na enumeração que fêz:

- abandono de cargo

- aplicação irregular dos dinheiros públiccs

- revelação de segrêdo conhecido em razão do cargo

- lesão aos cofres públicos e dilapidação do patrimônio nacional 
- corrupção passiva

- pleitear, como procurador ou intermediário, junto às repartições públicas (advocacia administrativa)

- receber propinas etc...

levando, assim, a confusão aos espíritos, pois parecia desconhecer que tudo isso já estava contido na expressão geral - crime contra a Administração Pública, que encabeçou a lista do art. 207. reparos:

A enumeração estatutária dos casos passíveis de demissão é digna de dois

\section{EMBRIAGUEZ HABITUAL}

A embriaguez, seja alcoólica ou não, pode ser eventual ou habitual. Da eventual ninguém está livre, participe ou não do fato uma determinante voluntária. Para essa, o Estatuto não indica a pena a aplicar quando essa é que deverá ser passível de punição.

Que fará a autoridade a um auxiliar seu que se apresente uma vez embriagado em serviço?

Promoverá sua demissão?

Não pode, porque a embriaguez não é habitual.

Suspendê-lo-á por uns tantos dias?

Não pode porque o fato não está capitulado entre as prcibições impostas ao funcionário.

Deixá-lo-á impune?

Não pode, porque o exemplo é pernicioso.

$\mathrm{E}$ então?

Nada mais resta, e tudo porque o legislador estatutário arriscou-se ao sempre perigoso - ubi lege distinguit... das enumerações.

Mas o que atinge as raias da aberração e da incultura é mandar demitir o ébrio habitual.

Não há quem saiba hoje que a embriaguez habitual, o alcoolismo, é doença a ser tratada por especialistas e não falta a ser punida pela autoridade.

De um lado, o legislador manda apcsentar com todos os vencimentos o funcionário atacado de alienação mental, em qualquer de suas formas; do outro manda demitir o alcoólatra. E como se, em pleno século XX, mandasse lapidar os loucos!...

\section{INSUBORDINAÇÃO}

$\mathrm{Na}$ enumeração que faz, usa o Estatuto de uma impropriedade, quando determina a demissão do servidor que praticar

"insubordinação grave em serviço"

Evidentemente, o que se quis dizer ali foi

- indisciplina grave em serviço - 
Com efeito, a indisciplina se revela pela desobediência às ordens recebidas, seja qual fôr o modo de o fazer; assim, a indisciplina pode ser leve ou grave: um servidor que, devendo chegar mais cedo ao expediente, não veio porque não quis, mas, quando interpelado pelo chefe, fica submisso, cabisbaixo, respeitoso, indisciplinou-se, mas não se insubordinou.

A insubordinação é sempre reação violenta contra o superior. Assim, se ao ser interpelado pelo chefe, o servidor faltoso the disse em tom áspero que não veio porque não quis, porque sua ordem era absurda, porque já está cansado da perseguição que o chefe the move... insubordinou-se.

A insubordinação é sempre grave: a indisciplina, não.

\section{GRADAÇÃO DA PENA}

Considerando os casos de demissão, o legislador incluiu, entre êles, os crimes contra a Administração Pública. Ora, nesse caso, o servidor terá que ser submetido à jurisdição do Poder Judiciário, cai na órbita do Direito Penal, ficando, pcrtanto, protegido pelo critério científico do julgamento, pois ali sua personalidade poder-1he-á servir de atenuante à prática do ato delituoso. Não importa que já o tenham demitido administrativamente: a absolvição no fôro criminal, a despeito da independência das responsabilidades, dar-lhe-á direito à reintegração, pois não poderá prevalecer o ato da autoridade administrativa contra a decisão jurídica de última instância.

O perigo está nos atos que não constituem crime, mas justificam a demissão.

\section{ABSURDO JURÍDICO}

Consideremos uma dessas faltas que não representam violação a nenhum dos dispositivos do Código Penal e que, por isso, subtraem o servidor à jurisdição do Poder Judiciário:

"exercer comércio ou participar de sociedade comercial, exceto como acionista, cotista ou comanditário".

Juntemos êsse ao dispositivo anterior:

"participar da gerência ou administração de emprêsa industrial ou comercial, salvo quando se tratar de cargo público de magistério".

Assim, um servidor qualquer pode participar de sociedade pcr cotas, de responsabilidade limitada. Não poderá, entretanto, ser gerente dela. Ora, é da essência de sociedade dessa natureza que, no silêncio do contrato, qualquer dos sócios poderá usar da firma social.

O uso da firma é ato de gerência; logo, qualquer dos servidores pertencentes a uma sociedade por cotas de responsabilidade limitada poderá, eventualmente, em casos dêsses, ser chamado a praticar ato de gerência.

Há, pois, necessidade de distinguir entre a prática sistemática da gerência e a prática de um ato de gerência, em circunstâncias especiais, para facilitar ou não prejudicar os negócios sociais.

Nem todos os atos de gerência poderiam assim caracterizar o dolo, sem o qual descabida a imposição da pena. 
Mas o Estatuto não permite essa indagação: praticou ato de gerência, será demitido!...

Isso não passa de rematado absurdo, de critério aberrante de qualquer cultura jurídica, indigno de figurar em código de país onde pontificam e pontificaram tantos luminares do Direito.

Não se indaga quanto tempo de serviço tem o funcionário faltoso, que comissões desempenhou, que elogios recebeu, qual sua utilidade para o serviço público... Nada disso importa: praticou ato de gerência, será demitido!

Ainda que ésse ato seja a simples assinaturá num cheque de pagamento cuja procrastinação seria danosa à sociedade!

E tudo por que? Porque o Estatuto se apegou à Escola Clássica de Criminologia, que faz do ato o único critério normativo da pena, quando o elaboraram posteriormente ao Código Penal vigente, onde predominam os princípios modernos da Escola Eclética!

Mas qual o julgador que, ao apreciar un fato dessa natureza, deixará de ládo considerações subjetivas, terá a desumanidade de impor a pena de demissão a um funcionário digno de encômios, quando a falta, a despeito da crueldade estutária, se the afigura leve?

Mas como poderá êle deixar de aplicar a pena draconiana, se do processo ficcu caracterizada a falta?

Tudo seria diferente se o legislador estatutário houvesse disposto, para 0 art. 207/EF, da seguinte forma:

"A pena de demissão pođerá ser aplicada nos casos de:"

Estaria assim o julgador habilitado a graduar a punição, conforme as circunstâncias do fato concreto, chegando, então, se necessário, à pena máxima.

\section{DEMISSÃO A BEM DO SERVIÇO PŨBLICO}

Mas existe coisa ainda digna de reparo.

Assin como não há pena autônoma de multa, pois essa resulta sempre da conversão da pena de suspensão, quanđo o serviço exigir a continuidade do trabalho, também não há pena de "demissão a bem do serviço públicc".

A pena é de "demissão" que, para certos casos, será seguida do adendo - "a bem do serviço público". Pelo menos é o que se infere dos têrmos estatutários porque, na reaiiciacie, aqueia expressão acrescentada à pena, mudalhe o caráter, tem fôrça de - pena acessoria, uma vez que é impeditiva de readmissäo, torna o servidor incompativel para o exercício de cargo ou função, mesmo em autarquias.

Evidentemente, existe aí uma restrição de direito essencial, pois, segundo a Constituição Federal, art. 145, parágrafo único, verbis:

"A todos é assegurado trabalho que possibilite existência digna. O trabalho é obrigação social."

Ora, não pode haver restrição de direito fora dos casos expressos em lei, pois, verbis:

"Ninguém pode ser obrigado a fazer ou deixar de fazer alguma coisa senão em virtude de lei" (CF/art. $141, \S 2 .^{\circ}$ ). 
Qual foi a lei que determinou não poder voltar à atividade o servidor demitido "a bem do serviço público"?

Não existe; a determinação partiu do Presidente da República, em despacho a uma expcsição do D.A.S.P.

E pcdia o Presidente da República, ou pode essa autoridade restringir direitos individuais?

Claro que não; logo, aquela decisão não tem vaìor jurídico.

É óbvio que, em certos casos, o funcionário demitido "a bem do serviço público", como por exemplo o peculatário, não deverá voltar à atividade do Esstado... tão cedo.

Mas aquela restrição, pela forma por que a entendem, não é limitada no tempo: é eterna, o que significa que nunca mais poderá o funcionário reabilitar-se!

Ora, isso atinge às raias da monstruosidade jurídica.

Na sistemática do Direito Criminal, admite-se a reabilitação e, em muitos casos, a interdição de direitos só se faz por prazo legalmente fixado. Para o peculatário, por exemplo demitido "a bem do serviço público", a sentença que o condenar à pena de reclusão e de multa, também ihe imporá a incapacidade para investidura em função pública, mas enquanto durar a execução da pena ou da medida de segurança detentiva que a acompanhar .

Assim, enquanto o Direito Crininal limita a incompatibilidade no tempo, o Direito Administrativo a mantém ad perpetuam!

Mas a contradição aí não existe só para com o Direito Criminal: ofende a própria sistemática da Constituição.

Com efeito, se o Senado condenar o Presidente da República por crime de peculato, priva-o do cargo e o considera incompatível para qualquer função pública pelo prazo máximo de cinco anos, limitando, destarte, a restrição de direito. Mas o funcionário, condenado pelo mesmo crime, e por decisão da mesma autoridade presidencial, nunca mais terá outra oportunidade de ingressar nos quadros do pessoal, como agente do Estado!...

Isso tudo considerado, não se pode deixar de concluir que o mandamento do art. 209/EF que determina o acréscimo da frase - "a bem do serviço público" à pena de demissão só tem valor moral, carecendo de qualquer efeito jurídico, como aberrante que é da doutrina e da lei e, assim, insustentável pelos Tribunais e Juízes.

\section{CASSAÇÃO DE APUSENTADORIA E DISPONIBILIDADE}

O funcionário em disponibilidade e o aposentado são inativos. Mas existe, entre êles, grande diferença: o que está em disponibilidade aguarda aproveitamento, é um servidor pronto a ser chamado a qualquer hora. Não se compreende, assim, que fique livre das normas disciplinares. A disponibilidade para o civil equivale à reserva para o militar.

O aposentado, ao contrário, é aquêle que foi afastado do serviço, presumivelmente, a título definitivo, recebendo do Estado proventos que lhe garantam a subsistência, seja como prêmio aos serviços que prestou, seja como de- 
corrência das conquistas sociais dos últimos tempos. A aposentadoria, para os civis, equivale à reforma dos militares. Não se compreende, assim, que o funcionário aposentado fique sujeito às mesmas normas disciplinares dos outros servidores.

Mas o legislador estatutário assim o entendeu.

Não se pode censurá-lo em aíguns casos, mas não deixa de haver excessivo, rigor, quando manda cassar a aposentadcria ao servidor que aceitou ilegalmente cargo ou função ou praticou usura.

Para o aposentado que aceitasse ilegalmente outro cargo ou função a pena deveria ser a perda do último cargo, $\mathrm{ccm}$ reposição do que houvesse dêle recebido. Não a perda do prêmio a que fêz jus, por serviços já prestados ou por desgaste físico comprovado.

$\mathrm{E}$ quanto à usura, é inconcebível a ojeriza do legislador estatutário pela agiotagem.

Que é coisa feia a uma, não se discute; que deve ser reprimida, não se contesta; mas que justifique a cassação da aposentadoria ou a demissão, é demais. A usura não é nobre, mas também não é infamante.

\section{RECURSO}

Quando o funcionáric se sente prejudicado por decisão da autoridade a que está subordinado, poderá pedir-lhe que reconsidere seu ato. Evidentemente, o pedido de reconsideração terá de ser formulado mediante argumentos oportunos. Se a reconsideração não fôr concedida, poderá o funcionário subir à instância imediatamente superior, para o mesmo fim. Terá, evidentemente, de fundamentar seu pedido.

A mesma coisa ocorre no fôro judiciário: os recursos são fundamentados, instruídos, mas não exigem, necessàriamente - e nem isso seria possível que, de cada vez, isto é, de uma instância para outra, formule o postulante argumentos inéditos.

O que se pretende, com os recursos, é deferir a nova autoridade o exame da mesma questão, o estudo dos mesmos fatos e a consideração, quiçá, dos mesmos argumentos.

A mesma processualística adotou o Estatuto vigente; no entanto, não se admite, na prática administrativa, renovação de recursos, senão quando, ao dirigir-se a uma nova instância, apresenta o funcionário novos argumentos. Ora, isso redunda em cercear o recurso, pois tais argumentos não podem ser assim tão variados. O que se deveria deferir à autoridade superior não eram os argumentos novos, mas nova apreciação dos mesmos argumentos, pois, não rarc, considera a instância superior relevantes as razões que a menor desprezou.

Como se vê, há, evidentemente, muita coisa a corrigir na penologia estatutária. Ela ainda se ressente do espírito medieval do Conde de Lippe e melhor seria adaptá-la às conquistas da Ciência, que ao discricionarismo de vontades reacionárias. 